
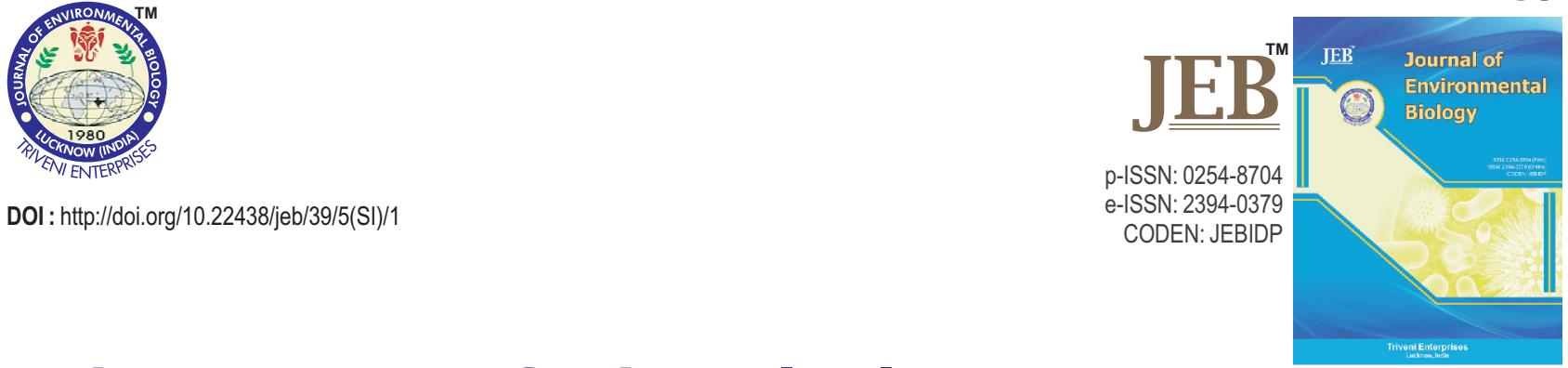

\title{
Enhancement of microalgal production through bacterial mineralization of ethylene glycol
}

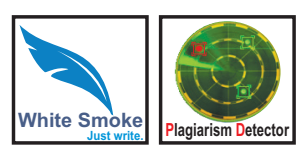

\section{Authors Info}

M. Kishi", M. Kawai', K. Tsuchiya ${ }^{2}$ M. Koyama ${ }^{3}$, N. Nagao ${ }^{4}$ and T. Toda

${ }^{1}$ Graduate School of Engineering, Soka University, Hachioji, Tokyo 192-8577, Japan

${ }^{2}$ Center for Regional Environmental Research, National Institute of Environmental Studies, Tsukuba, Ibaraki 305-0053, Japan

${ }^{3}$ School of Environment and Society, Tokyo Institute of Technology, Meguro, Tokyo 152-8550, Japan

${ }^{4}$ Laboratory of Marine Biotechnology, Institute of Bioscience, Universiti Putra Malaysia, 43400 Serdang, Selangor Darul Ehsan, Malaysia

${ }^{*}$ Corresponding Author Email : masa-kishi@soka.gr.jp

Key words

Algal-bacterial consortium Bacterial mineralization

Chlorella fusca

Ethylene glycol

Monoculture

Publication Info

Paper received : 09.06.2017

Revised received : 19.09 .2017

Re-revised received : 25.11 .2017

Accepted : 28.12.2017

\begin{abstract}
Aim: In this study, ethylene glycol was supplied to an algal-bacterial consortium to investigate the effect of bacterial mineralization of ethylene glycol on algal growth.

Methodology: Batch cultures of bacteria and Chlorella fusca monocultures, as well as algal-bacterial consortium were fed with $14,000 \mathrm{mg} \mathrm{l}^{-1}$ of ethylene glycol and incubated in one liter glass bottles at $25^{\circ} \mathrm{C}$ with light intensity of $300 \mu \mathrm{mol} \mathrm{m}^{-2} \mathrm{~s}^{-1}$ in a $12 \mathrm{hr}-$ light: $12 \mathrm{hr}$-dark cycle. A monoculture of $\mathrm{C}$. fusca without ethylene glycol was also cultured under similar conditions to test algal growth inhibition.

Results: In the consortium, there was more than 2-fold increase in the maximum algal specific growth rate and a 1.3-fold increase in the maximum bacterial specific growth rate. Furthermore, the maximum ethylene glycol removal efficiency by consortium was $89 \%$, while those by bacteria monoculture was $31 \%$. No apparent removal of ethylene glycol by the $C$. fusca monoculture was observed.

Interpretation: The enhancement of microbial growth rates and ethylene glycol degradation in consortium compared to monocultures indicates that symbiotic relationship between algae and bacteria enhanced oxygen and $\mathrm{CO}_{2}$ exchange between them, as a result promoting growth and ethylene glycol degradation. This study demonstrated the possibility of an algal-bacterial system for the production of microalgal biomass by feeding organic wastes, such as ethylene glycol-containing wastewater.
\end{abstract}

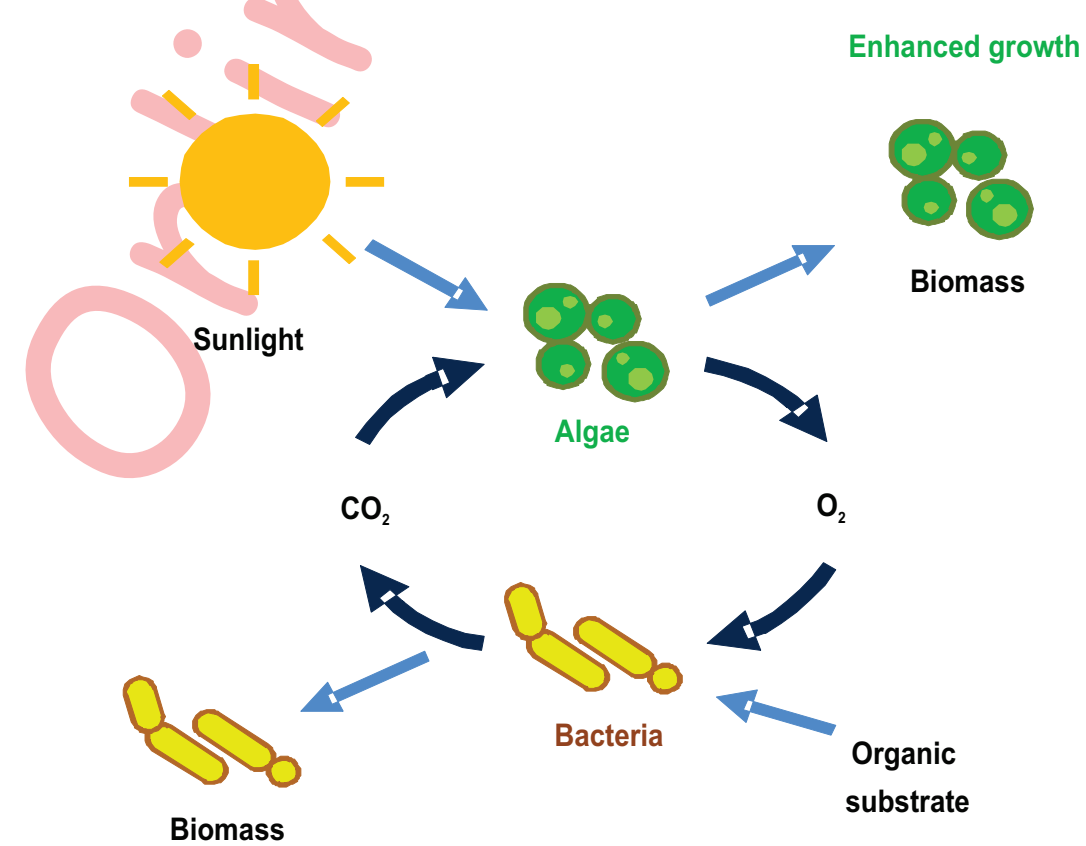




\section{Introduction}

Microalgal wastewater treatment can convert waste into useful biomass that can be used for various purposes including bioenergy production, and their application to anaerobic digestion effluent, manure, and municipal wastewater (González et al., 2008; Wang et al., 2010; Zhou et al., 2012; Ruiz-Martinez et al., 2012). In addition to the conventional organic wastewaters mentioned above, chemical-based organic wastewater has been problematic around the world. There is a strong need to investigate the applicability of microalgal processes to a wide range of wastewater types.

A large quantity of ethylene glycol $\left(E G ; \mathrm{C}_{2} \mathrm{H}_{6} \mathrm{O}_{2}\right)$ has been produced as a raw material for polyester resins, antifreeze/deicing fluids, cosmetics and surface coatings (ATSDR, 2010). For example, in the United States, more than 3.2 megatons of EG is produced annually (ATSDR, 2010). Wastewaters containing EG are globally discharged from plastic factories, airports and automobile maintenance factories (CERI and NITE, 2007). Since EG exhibits a high chemical oxygen demand (Switzenbaum et al., 2001; Staples and Gulledge, 2006), the effect of its wastewater onto the water environment cannot be neglected.

As a cost-effective wastewater treatment alternative, an algal-bacterial consortium has been applied to wastewaters containing various hazardous chemicals, including salicylate, acetonitrile and bisphenol A (Guieysse et al., 2002; Muñoz et al., 2005; Eio et al., 2014, 2015). The algal-bacterial system utilizes a symbiotic relationship between algae and bacteria, where bacteria use photosynthetically generated oxygen to degrade organic waste. Meanwhile, algae utilize carbon dioxide and nutrients produced through bacterial mineralization of the waste (Oswald et al., 1953). Consequently, with an algal-bacterial system, microalgae biomass is produced through organic waste treatment that uses less energy for aeration.

Previous studies have shown that some microalgae such as Chlorella protothecoides (Kishi et al., 2015) and Chlorella regularis (Endo et al., 1974) can heterotrophically utilize EG for growth, but not all (Kishi et al., 2015). Contrarily, an algal-bacterial system can be constructed with virtually any photosynthetic microalgae with the aid of bacterial decomposition of the organic fraction.

In the view of microalgal biomass production, bacterial symbiosis may not only support $\mathrm{CO}_{2}$ and nutrients delivery, but may also reduce the cost and energy required to maintain the system. In order to evaluate the algal-bacterial system as a microalgal biomass production using wastewater, it is necessary to investigate the effects of bacterial co-culture onto the biomass productivity and wastewater treatment efficiency. Therefore, in this study microalgal productivity and EG removal rate of algal-bacterial system with algae-only and bacteria-only cultures was compared.

\section{Materials and Methods}

Microorganisms and pre-culture: Chlorella fusca, which has been applied to the treatment of chemical wastewaters (Wehrheim and Wettern, 1994; Tsuji et al., 2003; Hirooka et al., 2005), was in this experiment. C. fusca NIES-2151 was obtained from the National Institute of Environmental Studies (Tsukuba, Japan). Bacterial inoculum free of bacterivorous or algivorous protists was obtained by filtering the activated sludge (Kitano Sewage Treatment Plant, Tokyo, Japan) through GF/C filter (Whatman, UK). Both organisms were individually incubated with mineral salt medium (MSM) (Muñoz et al., 2004) incorporated with $14,000 \mathrm{mgl}^{-1}$ of ethylene glycol (EG) as pre-culture.

Experimental setup : In order to compare the EG utilization characteristics by each microorganisms, three different treatments were prepared: (1) C. fusca, (2) bacteria, and (3) algalbacterial consortium. Additionally, (4) C. fusca without EG (C. fusca-EG) was prepared to identify EG inhibitive effect on algal growth. In total four treatments were conducted in triplicates. Mineral salt medium (MSM) was used as culture medium and all, except $C$. fusca-EG, received $14,000 \mathrm{mg} \mathrm{l}^{-1}$ of $E G$ in the medium. Assuming the complete mineralization of $E G$ in the medium with algal-bacterial consortium, the $\mathrm{C} / \mathrm{N}$ ratio of $\mathrm{EG}$ and medium nitrate was calculated to be approximately 36.5. Pre-cultures were centrifuged and washed with EG-free MSM, and inoculated as indicated in Table 1. The initial concentration of algae was adjusted to $35 \mathrm{mg} \mathrm{d}$. wt. $\mathrm{I}^{-1}$, and bacterial initial dry weight was set at $5 \mathrm{mg} \mathrm{l}^{-1}$.

Culture medium was injected into one liter cylindrical glass bottles (Fig. 1). Head spaces were continuously replaced with aseptic air through $0.2 \mu \mathrm{m}$ air filters (Millipore, Aervent-50, USA) at $0.5 \mathrm{I} \mathrm{min}^{-1}$ to simulate the air condition of in situ algalbacterial reactors. The cultures were mixed with magnetic stirrers, approximately, at $150 \mathrm{rpm}$. The culture bottles were incubated at $25^{\circ} \mathrm{C}$ with light intensity of $300 \mu \mathrm{mol} \mathrm{m} \mathrm{m}^{-2} \mathrm{~s}^{-1}$ (fluorescent lamp) in a $12 \mathrm{hr}$-light:12 hr-dart cycle for 14.5 days. Samples were taken every $12 \mathrm{hr}$ for the first 2 days (day $0,0.5,1$, $1.5,2$ ), immediately after every light period from day 2.5 to day 7.5 (day $2.5,3.5,4.5,5.5,6.5,7.5$ ), and after every other light period from day 8.5 to the end of the experiment (day 8.5, 10.5, 12.5, 14.5).

Table 1: Experimental setup

\begin{tabular}{lll}
\hline Run & Organisms & Ethylene glycol $\left(\mathrm{mgl}^{-1}\right)$ \\
\hline Consortium & C. fusca+Bacteria & 14,000 \\
Bacteria & Bacteria & 14,000 \\
C. fusca & C. fusca & 14,000 \\
C. fusca-EG & C.fusca & 0 \\
\hline
\end{tabular}




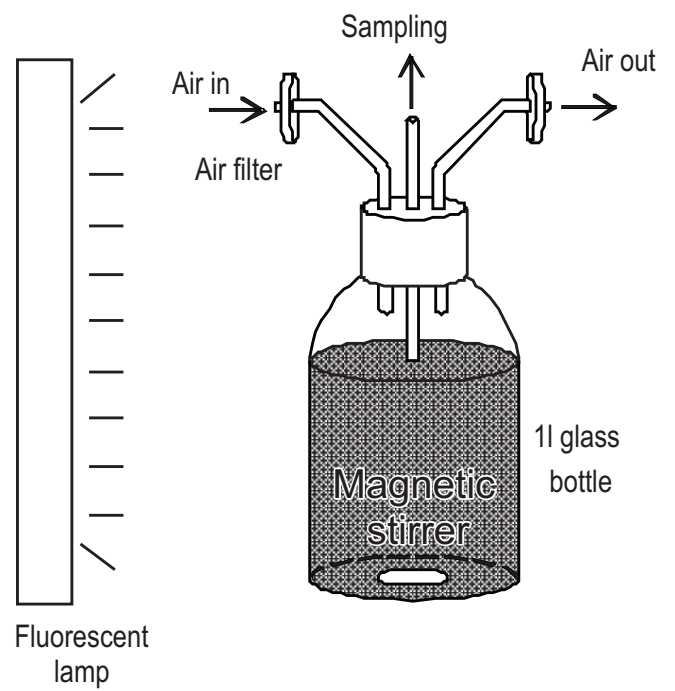

Fig. 1 : Schematic diagram of experimental apparatus

Analytical procedures : Ethylene glycol concentration was determined using a gas chromatograph equipped with a packed column (Shincarbon A) and flame ionization detector (Shimadzu, GC-9A, Japan). The column was maintained at $140^{\circ} \mathrm{C}$, and both injector and detector temperatures were $280^{\circ} \mathrm{C}$. The carrier gas was helium and was introduced at $40 \mathrm{ml} \mathrm{min}^{-1}$. Dissolved oxygen (DO) was measured using a portable DO meter (Mettler Toledo AG, SG68, Switzerland), and pH was measured with a portable pH meter (Shindengen, KS723, Japan). Algal cells and bacterial cells were counted with a fluorescent microscope (Zeiss, Germany) using epifluorescence and a fluorescent dye (SYBR Gold, Thermo Fisher, USA) as previously reported (Shibata et al.., 2006), respectively. To separate algal-bacterial flocs, samples were sonicated for about 5 mins before measurements. Nutrients were analyzed with a nutrient analyzer (SWAAT, BL-TEC, Japan). Specific growth rate $\left(\mu\right.$; day $\left.{ }^{-1}\right)$ was calculated using the following equation:

$$
\mu=\frac{\ln \left(\mathrm{x}_{2} / \mathrm{x}_{1}\right)}{\mathrm{t}_{2}-\mathrm{t}_{1}}
$$

where, $x_{i}$ is cell count (cells m $\left.{ }^{-1}\right)$ at time $t_{i}(\mathrm{~d})$.

\section{Results and Discussion}

$\mathrm{pH}, \mathrm{DO}$ and algal/bacterial growth : The variations of $\mathrm{pH}$ in $\mathrm{C}$. fusca and C. fusca-EG were relatively small, and it increased slightly from 6.8 to 7.2 during the experimental period in both cultures (Fig. 2a). On the other hand, the variation was much larger in bacteria and consortium. The $\mathrm{pH}$ in these cultures initially rose up to over 8 , probably owing to the rapid consumption of nitrate (Fig. 3a), and then dropped later on, especially in the consortium. The cause of $\mathrm{pH}$ reduction could be $\mathrm{CO}_{2}$ production with a large amount of EG decomposition (Fig. 4a).
Dissolved oxygen (DO) in C. fusca and C. fusca-EG remained near or over saturation throughout the experimental period (Fig. 2b). On the other hand, DO was rapidly consumed in consortium and bacterial cultures; on Day 1.5, DO dropped to less than $0.1 \mathrm{mg} \mathrm{l}^{-1}$ and remained near $0 \mathrm{mg} \mathrm{l}^{-1}$ till the end of the experiment. Even in the consortium, despite the photosynthetic oxygen supply, bacteria consumed most of the oxygen, implying that oxygen was a limiting agent in decomposition of EG.

Algal cell counts of $C$. fusca and $C$. fusca-EG were similar (Fig. 2c), and there was no significant difference between the two (Student's t-test; $p>0.05)$, except for Day $14.5(p=0.04)$. Almost no inhibitive effect of $E G$ onto algal growth was observed as both C. fusca and C. fusca-EG showed similar values in pH, DO and algal cell counts (Fig. 2a,b,c). Algal cell count in algal-bacterial consortium was 3.5 and 4.2 times higher than C. fusca on Day 2.5 and 6.5, respectively (Fig. 2c). Similarly, bacterial cell count was 2 to 5 times higher than bacteria-only culture after Day 2.5 (Fig. 2d).

Nitrate $\left(\mathrm{NO}_{3}\right)$ and nitrite $\left(\mathrm{NO}_{2}\right)$ concentrations reached near depletion both in bacteria and consortium culture on Day 6.5 (Fig. 3a,b). In these cultures, $\mathrm{NO}_{3}$ seemed to have been firstly reduced into $\mathrm{NO}_{2}$ for the utilization by bacteria and microalgae. In the algae-only cultures, $\mathrm{NO}_{2}^{-}$increased towards the end of the experiment (Fig. 3b), probably due to the reduction of $\mathrm{NO}_{3}$. A slight decrease of $\mathrm{NO}_{3}$ could have been the sum of the reduction into $\mathrm{NO}_{2}$ and assimilation by the algae. Phosphate exhibited less variation likely owing to its less requirement compared to nitrogen (Fig. 3c).

After the depletion of $\mathrm{NO}_{3}^{-}$and $\mathrm{NO}_{2}$, the algal growth almost ceased in consortium after Day 6.5, probably owing to the depletion of nutrients (Fig. 3) or oxygen (Fig. 2b). The bacterial growth rate also reduced after Day 6.5 , similarly to the algal growth.

In this study, both algal and bacterial cell growth were enhanced in algal-bacterial consortium compared to algae-only and bacteria-only cultures (Fig. 2c,d). The maximum algal specific growth rates were 0.46 and $0.96 \mathrm{~d}^{-1}$ for $\mathrm{C}$. fusca and consortium, respectively, exhibiting more than 2-fold increase. The maximum bacterial specific growth rates were 1.45 and 1.94 $\mathrm{d}^{-1}$ for bacteria and consortium, respectively, demonstrating bacterial growth promotion in the consortium. In an open pond system without vigorous aeration, inorganic carbon supply often limits the growth of microalgae (Campbell et al., 2011), as surface atmospheric $\mathrm{CO}_{2}$ gas transfer does not often meet the requirement. In this study, the growth of algae-only cultures could have been limited by inorganic carbon availability. Contrarily, in the algae-bacterial consortium, the bacterial decomposition of EG must have likely produced $\mathrm{CO}_{2}$ as byproduct, which raised the limitation and enhanced the algal growth rate. In turn, bacterial growth was likely limited by oxygen availability in bacteria-only culture, but photosynthetic oxygen supply enhanced the bacterial activity in the consortium. Therefore, as previous studies have 

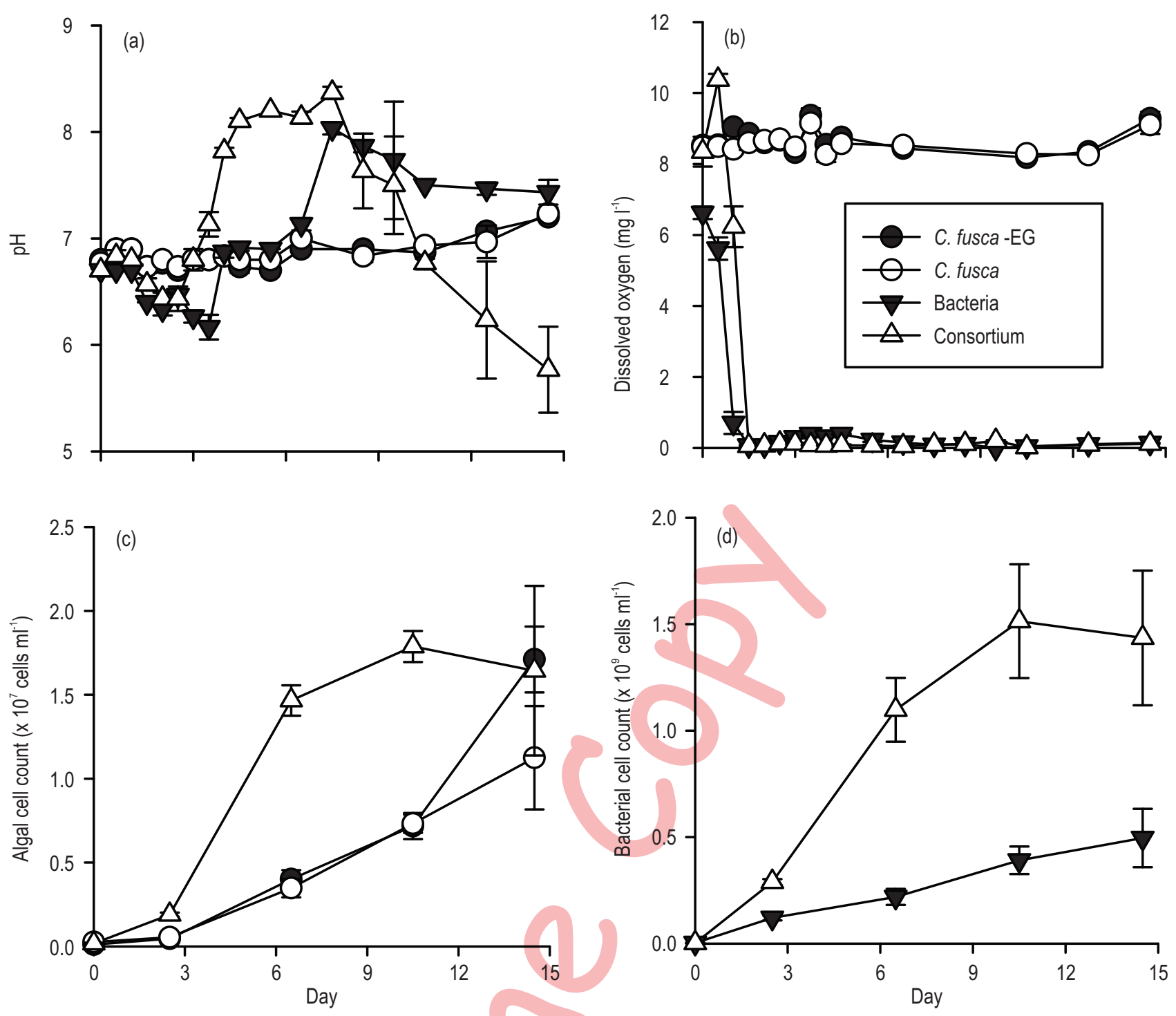

Fig. 2 : Environmental and biological parameters studied during the experiment: (a) pH, (b) dissolved oxygen, (c) algal cell count and (d) bacterial cell count

suggested (Oswald et al., 1953; Bell, 1980; Imase et al., 2008), this study reconfirmed that microalgae and bacteria can create a symbiotic relation, in which growth is enhanced through the accelerated exchange of oxygen and $\mathrm{CO}_{2}$ within the small community of microorganisms. It was shown in this study that, by providing a carbon source into an algal-bacterial system, biomass production can be greatly enhanced in an open pond without vigorous aeration.

Ethylene glycol removal : Ethylene glycol removal efficiency was highest in consortium; the removal efficiency was $89 \%$ with the final concentration of $1.56 \mathrm{~g} \mathrm{I}^{-1}$ (Fig. 5). The EG removal efficiency in bacterial culture remained $31 \%$, and no apparent decrease of EG was observed in C. fusca culture. Since C. fusca did not seem to decompose EG, the degradation in the consortium culture should have been mostly achieved by bacterial activity.

Consortium decomposed three times more EG than bacteria-only culture, probably owing to the enhanced bacterial activity induced by photosynthetic oxygen supply (Imase et al., 2008). The decomposed EG was likely decomposed into $\mathrm{CO}_{2}$, which should have been eventually assimilated into algal biomass. Through the algal-bacterial system, the organic compounds were converted into algal biomass through bacterial mineralization.

This study also demonstrated that algal-bacterial system can be applied to a medium with high chemical oxygen demand 

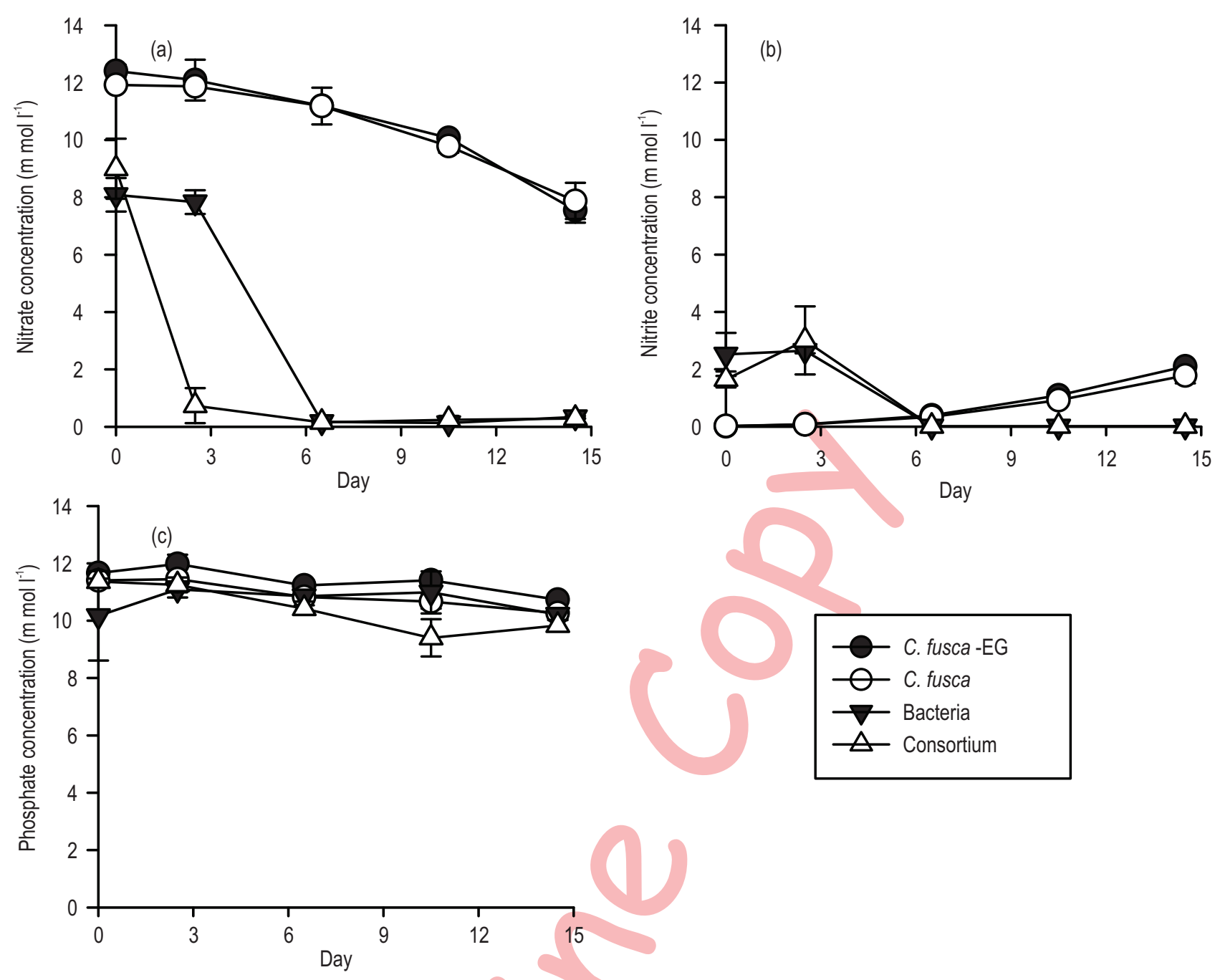

Fig. 3: Nutrients concentration: (a) nitrate $\left(\mathrm{NO}_{3}{ }^{-}\right),\left(\right.$b) nitrite $\left(\mathrm{NO}_{2}\right)$, (c) phosphate $\left(\mathrm{PO}_{4}{ }^{-}\right)$
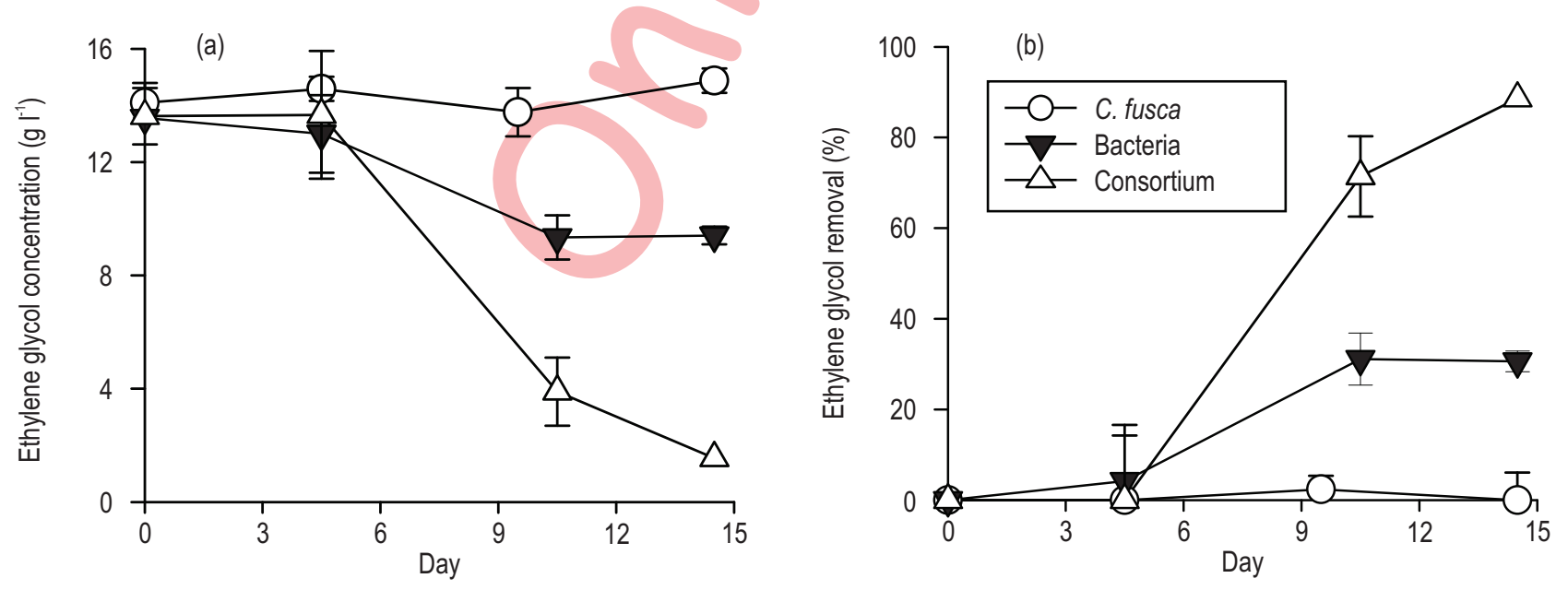

Fig. 4 : Ethylene glycol: (a) concentration and (b) removal rate 
(COD). In this study, estimated initial COD was $18 \mathrm{gl}^{-1}$, which was much higher than other algal-bacterial studies, ranging from several hundred milligram per litre (Picot et al., 1991; García et al., 2006), several gram per litre (Muñoz et al., 2005; Riaño et al., 2011), up to $4.3 \mathrm{~g} \mathrm{I}^{-1}$ (de Godos et al., 2009). In this study, It was found that as long as there was enough lighting and nutrients, an algal-bacterial system could convert a large portion of organic materials into algal and bacterial biomass.

The low DO (Fig. 3), however, indicated that oxygen limitation certainly occurred during the treatment process with algal-bacterial consortium. The cause of this oxygen limitation could be ceasing of algal growth owing to the depletion of nutrients. Since the $\mathrm{C} / \mathrm{N}$ ratio of the current study (approximately 36.5) was much higher than an ordinary algal $\mathrm{C} / \mathrm{N}$ ratio of 7 (Geider and Roche, 2002), nitrogen supply was much lower than the requirement. $\mathrm{The}^{\mathrm{NO}_{3}}$ and $\mathrm{NO}_{2}^{-}$in the medium was, therefore, quickly utilized by the microorganisms at the beginning of the experiment (Fig. 3a,b). For the latter days of experiment, autophagous decomposition of chlorophyll a may have occurred in reaction to $\mathrm{N}$ limitation (Ito et al., 2013; Ren et al., 2014), as a change in color from deep green into brown was observed in all three bottles of the consortium. For future study, addition of a sufficient amount of nitrogen may further enhance biomass production and EG removal efficiencies.

This study compared algal-bacterial treatment of ethylene glycol with treatment by bacteria and algae monoculture. The growth of microorganisms was greatly enhanced in the consortium, probably owing to the production of oxygen by algae and utilization of $\mathrm{CO}_{2}$ generated from oxidation of organic compounds. This study demonstrated that bioconversion of ethylene glycol into microalgal biomass is possible with an algal-bacterial system.

\section{Acknowledgments}

This research was supported by Japan Science and Technology Agency (JST)/Japan International Cooperation Agency (JICA), Science and Technology Research Partnership for Sustainable Development (SATREPS). Authors would like to express gratitude to the Kitano Sewage Treatment Plant (Tokyo, Japan) for providing the activated sludge used in this research.

\section{References}

Agency for Toxic Substances and Disease Registry (ATSDR): Toxicological Profile for Ethylene Glycol. Atlanta, GA(2010).

Bell, W.H.: Bacterial utilization of algal extracellular products. 1. The kinetic approach. Limnol. Oceanogr., 25, 1007-1020 (1980).

Campbell, P.K., T. Beer and D. Batten: Life cycle assessment of biodiesel production from microalgae in ponds. Bioresour. Technol., 102, 50-56 (2011).

Chemicals Evaluation and Research Institute (CERI) and National Institute of Technology and Evaluation (NITE): Primary Report on
RiskAssessment of Chemical Substances Ver.1.0 No.34 Ethylene Glycol. Tokyo (2007).

de Godos, I., S. Blanco, P.A. García-Encina, E. Becares and R. Muñoz: Long-term operation of high rate algal ponds for the bioremediation of piggery wastewaters at high loading rates. Bioresour. Technol., 100, 4332-9 (2009).

Eio, E.J., M. Kawai, C. Niwa, M. Ito, S. Yamamoto and T. Toda: Biodegradation of bisphenol $\mathrm{A}$ by an algal-bacterial system. Environ. Sci. Pollut. Res., 22, 15145-15153 (2015).

Eio, E.J., M. Kawai, K. Tsuchiya, S. Yamamoto and T. Toda: Biodegradation of bisphenol A by bacterial consortia. Int. Biodeterior. Biodegrad., 96, 166-173 (2014).

Endo, H., K. Nakajima, R. Chino and M. Shirota: Growth characteristics and cellular components of Chlorella regularis, heterotrophic fast growing strain. Agric. Biol. Chem., 38, 9-18 (1974).

García, J., B.F. Green, T. Lundquist, R. Mujeriego, M. Hernández-Mariné and W.J. Oswald: Long term diurnal variations in contaminant removal in high rate ponds treating urban wastewater. Bioresour. Technol., 97, 1709-15(2006).

Geider, R. and J. La Roche: Redfield revisited: variability of C:N:P in marine microalgae and its biochemical basis Redfield revisited: Variability of $\mathrm{C}: \mathrm{N}$ :Pin marine microalgae and its biochemical basis. Eur. J. Phycol., 37, 37-41 (2002).

González, C., J. Marciniak, S. Villaverde, P. A. García-Encina and R. Muñoz: Microalgae-based processes for the biodegradation of pretreated piggery wastewaters. Appl. Microbiol. Biotechnol., 80, 891-8 (2008).

Guieysse, B., X. Borde, R. Muñoz, R. Hatti-kaul, C. Nugier-chauvin, H. Patin and B. Mattiasson: Influence of the initial composition of algal-bacterial microcosms on the degradation of salicylate in a fed-batch culture. Biotechnol. Lett., 24, 531-538 (2002).

Hirooka, T., H. Nagase, K. Uchida, Y. Hiroshige, Y. Ehara, J. Nishikawa, T. Nishihara, K. Miyamoto and Z. Hirata: Biodegradation of bisphenol A and disappearance of its estrogenic activity by the green alga Chlorella fusca var. vacuolata. Environ. Toxicol. Chem., 24, 1896-901 (2005).

Imase, M., K. Watanabe, H. Aoyagi and H. Tanaka: Construction of an artificial symbiotic community using a Chlorella-symbiont association as a model. FEMS Microbiol. Ecol., 63, 273-82 (2008).

Ito, T., M. Tanaka, H. Shinkawa, T. Nakada, Y. Ano, N. Kurano, T. Soga and M. Tomita: Metabolic and morphological changes of an oil accumulating trebouxiophycean alga in nitrogen-deficient conditions. Metabolomics, 9, 178-187 (2013).

Kishi, M., M. Kawai and T. Toda: Heterotrophic utilization of ethylene glycol and propylene glycol by Chlorella protothecoides. Algal Res., 11, 428-434 (2015).

Muñoz, R., M. Jacinto, B. Guieysse and B. Mattiasson: Combined carbon and nitrogen removal from acetonitrile using algal-bacterial bioreactors. Appl. Microbiol. Biotechnol., 67, 699-707 (2005).

Muñoz, R., C. Köllner, B. Guieysse and B. Mattiasson: Photosynthetically oxygenated salicylate biodegradation in a continuous stirred tank photobioreactor. Biotechnol. Bioeng., 87, 797-803 (2004).

Oswald, W.J., H.B. Gotaas, H.F. Ludwig and V. Lynch: Algae symbiosis in oxidation ponds - III. Photosynthetic oxygenation. Sewage Ind. Waste., 25, 692-705 (1953).

Picot, B., H. El Halouani, C. Casellas, S. Moersidik and J. Bontoux: Nutrient removal by high rate pond system in a Mediterranean climate (France). Water Sci. Technol., 23, 1535-1541 (1991).

Ren, C., J. Liu and Q. Gong: Functions of autophagy in plant carbon and 
nitrogen metabolism. Front. Plant Sci., 5, 301 (2014).

Riaño, B., B. Molinuevo and M.C. Garcia-González: Treatment of fish processing wastewater with microalgae-containing microbiota. Bioresour. Technol., 102, 10829-33 (2011).

Ruiz-Martinez, A., N. Martin Garcia, I. Romero, A. Seco and J. Ferrer: Microalgae cultivation in wastewater: Nutrient removal from anaerobic membrane bioreactor effluent. Bioresour. Technol., 126, 247-253 (2012).

Shibata, A., Y. Goto, H. Saito, T. Kikuchi, T. Toda and S. Taguchi: Comparison of SYBR Green I and SYBR Gold stains for enumerating bacteria and viruses by epifluorescence microscopy. Aquat. Microb. Ecol., 43, 223-231 (2006).

Staples, C.A. and W. Gulledge: An environmental fate, exposure and risk assessment of ethylene oxide from diffuse emissions. Chemosphere, 65, 691-8 (2006).

Switzenbaum, M.S., S. Veltman, D. Mericas, B. Wagoner and T. Schoenberg: Best management practices for airport deicing stormwater. Chemosphere, 43, 1051-62 (2001).

Tsuji, N., T. Hirooka, H. Nagase, K. Hirata and K. Miyamoto: Photosynthesis-dependent removal of 2,4-dichlorophenol by Chlorella fusca var. vacuolata. Biotechnol. Lett., 25, 241-244 (2003).

Wang, L., Y. Li, P. Chen, M. Min, Y. Chen, J. Zhu and R.R. Ruan: Anaerobic digested dairy manure as a nutrient supplement for cultivation of oil-rich green microalgae Chlorella sp. Bioresour. Technol., 101, 2623-8(2010).

Wehrheim, B. and M. Wettern: Biosorption of cadmium, copper and lead by isolated mother cell walls and whole cells of Chlorella fusca. Appl. Microbiol. Biotechnol., 41, 725-728 (1994).

Zhou, W., Y. Li, M. Min, B. Hu, H. Zhang, X. Ma, L. Li, Y. Cheng, P. Chen and R. Ruan: Growing wastewater-born microalga Auxenochlorella protothecoides UMN280 on concentrated municipal wastewater for simultaneous nutrient removal and energy feedstock production. Appl. Energy, 98, 433-440 (2012).
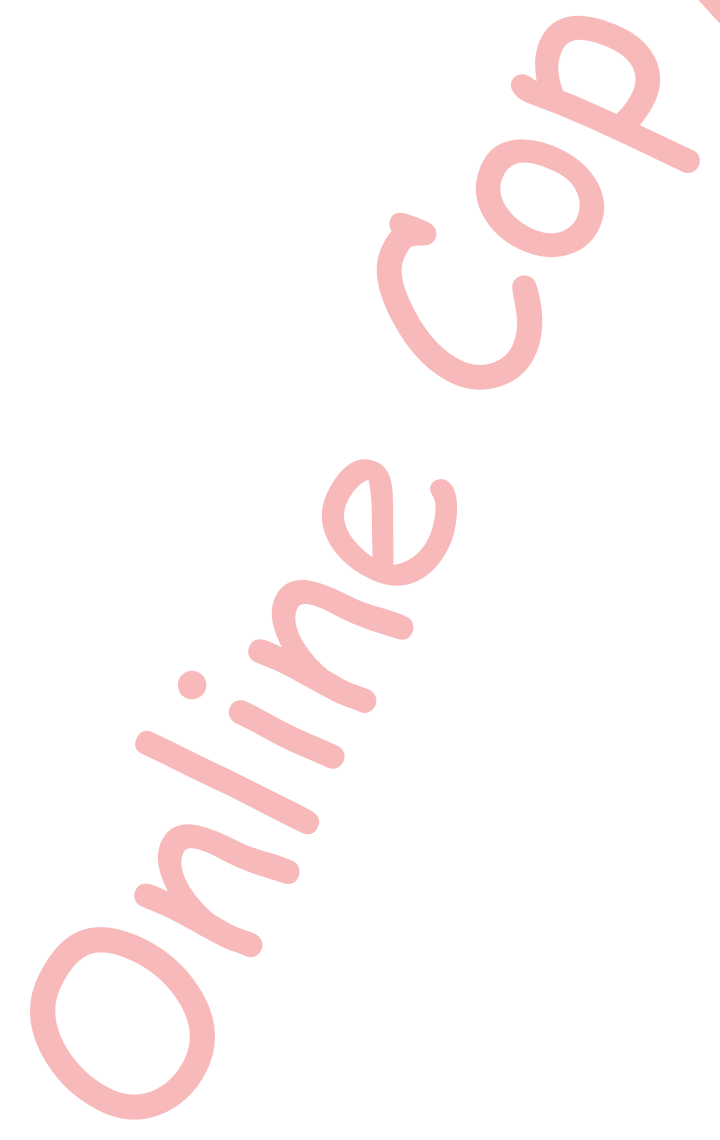